\title{
Transthyretin gene mutations in British and French patients with amyloid neuropathy
}

\author{
K Bhatia, M Reilly, D Adams, M B Davis, C H Hawkes, P K Thomas, G Said, \\ A E Harding
}

\begin{abstract}
Five patients, two British and three French, with late onset amyloid neuropathy were found to have mutations of the transthyretin (TTR) gene associated with the Portuguese and German types of familial amyloid polyneuropathy. Familial amyloid polyneuropathy is rare in the United Kingdom and has not previously been defined at a molecular genetic level. None of the patients had a history of affected antecedents; the role of TTR gene analysis in diagnosing known or suspected amyloid neuropathy, regardless of family history or ethnic background, is emphasised.
\end{abstract}

(f Neurol Neurosurg Psychiatry 1993;56:694-697)

Familial amyloid polyneuropathies are a clinically and genetically heterogeneous group of autosomal dominant disorders. ${ }^{1}$ The most common type was first described in Portugal, ${ }^{2}$ where the disease is endemic and over 500 kindreds have been reported. ${ }^{34}$ The clinical picture is of a predominantly sensory neuropathy, often with early autonomic dysfunction. The onset is insidious, usually between the ages of 20 and 40 years, with loss of pain and temperature sensation in the feet often associated with painful paraesthesiae. Distal muscle weakness, wasting and loss of tendon reflexes and of other sensory modalities occur later. Amyloid may be deposited in other tissues including the kidneys, heart, and vitreous body, but the clinical manifestations are mostly related to the peripheral neuropathy. The condition is slowly progressive and death usually occurs about 10 years after onset. ${ }^{35}$ The amyloid fibril protein deposited in the tissues of these patients is related immunologically to the transport protein transthyretin (TTR), previously known as prealbumin. ${ }^{6}$ In the Portuguese type a single base substitution in the TTR gene produces an amino acid substitution of methionine for valine at position 30 of the TTR protein, ${ }^{7}$ and creates a new recognition site for the restriction endonuclease Nsi $I$ which can be detected by a TTR cDNA probe. ${ }^{8}$ Other foci of familial amyloid polyneuropathy with a similar clinical picture and the same TTR gene mutation have been reported from Japan, Sweden, Brazil,
Italy, Greece, Majorca, Cyprus, and France. ${ }^{149}$

At least 14 different point mutations of the TTR gene associated with familial amyloid polyneuropathies have been reported to date. ${ }^{1210-20}$ Some clinical features are associated with specific TTR variants; although early distal loss of pain and temperature in the legs is common in all of them, the carpal tunnel syndrome, heart and vitreous involvement, late onset, and a more generalised sensory neuropathy may be prominent in some (table). Nevertheless, it is rarely possible to judge which TTR mutation is responsible for the disease in an individual case, unless the patient's ethnic background provides a clue. As in Portugal, many of these disorders have been labelled according to the origin of the families described-for example, the Maryland/German, ${ }^{15}$ Appalachian, ${ }^{16}$ and Jewish types. ${ }^{10}$ Importantly, some TTR variants are associated with cardiomyopathy but do not seem to affect peripheral nerve. ${ }^{14}$ Also, not all types of familial amyloid polyneuropathy are associated with deposition of abnormal TTR; in the Iowa (van Allen) and Finnish varieties the amyloid is derived from apolipoprotein AII and gelsolin respectively. ${ }^{21} 22$

To date, none of the known TTR gene defects has been reported in patients from the United Kingdom, where familial amyloid polyneuropathy seems to be rare. Here we

Table TTR related amyloid neuropathies: well characterised variants and clinical features from published work

\begin{tabular}{|c|c|c|c|}
\hline $\begin{array}{l}T T R \\
\text { variant }\end{array}$ & $\begin{array}{l}\text { Ethnic } \\
\text { origin }\end{array}$ & $\begin{array}{l}\text { Clinical features } \\
\text { (prominent other } \\
\text { sites of amyloid) }\end{array}$ & $\begin{array}{l}\text { Reference } \\
\text { No }\end{array}$ \\
\hline Met30 & Portugal & SAN & $2-9,25$ \\
\hline Ile33 & Jewish & SAN (vitreous) & \\
\hline Leu33 & Poland (USA) & SAN & 11 \\
\hline Pro36 & Greece (USA) & SAN (cardiac) & 12 \\
\hline Gly42 & Japan & SAN & 13 \\
\hline Ala49 & Italy & SAN (cardiac, vitreous) & 14 \\
\hline Arg50 & Japan & SAN & 13 \\
\hline His58 & $\begin{array}{l}\text { Germany } \\
\text { (Maryland) }\end{array}$ & SAN, CTS & 15 \\
\hline Ala60 & $\begin{array}{l}\text { Ireland } \\
\text { (Appalachian) }\end{array}$ & Late onset SAN (cardiac) & 16,26 \\
\hline $\begin{array}{l}\text { Leu64 } \\
\text { Tyr77 }\end{array}$ & Italy (USA) & $\begin{array}{l}\text { SAN, CTS (cardiac) } \\
\text { Late onset SAN, CTS }\end{array}$ & 11 \\
\hline & $\begin{array}{l}\text { Switzerland } \\
\text { (Indiana) }\end{array}$ & SAN, CTS (vitreous) & 18 \\
\hline $\begin{array}{l}\text { Asn90 } \\
\text { Cys114 }\end{array}$ & $\begin{array}{l}\text { Italy } \\
\text { Japan }\end{array}$ & $\begin{array}{l}\text { SAN (cardiac, vitreous) } \\
\text { SAN }\end{array}$ & $\begin{array}{l}19 \\
20\end{array}$ \\
\hline
\end{tabular}

*Presumed origin of affected antecedents, with place of residence of patients in reported cases in brackets. SAN = sensory/autonomic neuropathy.

CTS $=$ carpal tunnel syndrome. 
describe two British patients with amyloid neuropathy, neither of whom had affected relatives or a relevant ethnic background, who were found to have pathogenic TTR gene mutations. One had the met30 mutation, and the other the tyr77 mutation hitherto described in only two families, one German-American and one French. ${ }^{1723} \mathrm{We}$ also report on three further French patients with the tyr77 mutation who gave no history of affected ancestors but are probably related to the kindred described by Satier et al. ${ }^{23}$

\section{Patients, methods, and results \\ Methods}

DNA was extracted from blood $(10-20 \mathrm{ml})$ by standard procedures. Amplification of exon 2 of the TTR gene was carried out as described by Abbot and Povey. ${ }^{24}$ For exon 3, $1 \mu \mathrm{l}$ DNA was amplified using the polymerase chain reaction in a Hybaid Intelligent heating block using oligonucleotide primers CTCCATGCGTAACTTAATCC $\left(5^{\prime}\right.$ to TTR exon 3) and GCCAGATGTGTTTTGGAATG ( 3 ' to TTR exon 3) for 30 cycles, comprising denaturing at $90^{\circ} \mathrm{C}$ for $10 \mathrm{~s}$, annealing at $50^{\circ} \mathrm{C}$ for $30 \mathrm{~s}$, and elongation at $70^{\circ} \mathrm{C}$ for $30 \mathrm{~s}$. The products of the polymerase chain reaction were digested with $N s i$ $I$ (exon 2) and Ssp I (exon 3) according to the manufacturer's instructions (Northumbria Biologicals, UK) before electrophoresis for 45 minutes in $4 \%$ agarose NuSieve (FMC Bioproducts, Maine, USA), staining with ethidium bromide, and inspection under ultraviolet light.

\section{Case 1}

A 69 year old man developed sequential bilateral visual loss due to vitreous opacities over a few months at the age of 63 years. A right vitrectomy was performed. At about this time he experienced distal tingling, numbness, and subsequently weakness of his legs, which later spread to his hands. He had occasional constipation or diarrhoea and orthostatic dizziness. There was no family history of neuropathy. The patient's mother died in her 60 s of a cerebral haemorrhage attributed to hypertension and his father in his 80 s of a myocardial infarction. He had four maternal half siblings and three full siblings. His family came from Suffolk and there was no known Swedish or Portuguese or other Mediterranean ancestry. On examination the pupils were small and the left did not react to light. $\mathrm{He}$ had mild bilateral sensorineural deafness. $\mathrm{He}$ had wasting and weakness of the small muscles of his hand, of his forearm muscles, and of the anterior tibial compartments. Ankle jerks were absent. There was patchy distal loss of all sensory modalities, position sense being least affected. His blood pressure was $130 / 90 \mathrm{~mm} \mathrm{Hg}$ lying and $110 / 85 \mathrm{~mm} \mathrm{Hg}$ standing.

Electromyography showed evidence of denervation in distal and proximal muscles. The median, ulnar, radial, and sural sensory action potentials were absent. Motor nerve conduction velocities in the ulnar, tibial, and peroneal nerves were normal or slightly reduced and slow in the median nerve $(29 \mathrm{~m} / \mathrm{s})$, with small compound muscle action potentials. Routine haematological and biochemical tests gave normal results except for a mildly raised creatine kinase activity (248 IU/1), and there was no evidence of paraproteinaemia on protein electrophoresis. Rectal biopsy showed amyloid deposition which gave a positive reaction to a monoclonal antibody to TTR (provided by Professor P Collins). A sural nerve biopsy also showed small endoneurial deposits of amyloid, but sections used for TTR staining contained no amyloid.

\section{Case 2}

A 60 year old man was seen in 1989 with a two year history of distal numbness and more recent stabbing pains in his feet; about six months after onset in his legs he noticed similar symptoms in his hands. Five years earlier he had had surgery for bilateral carpal tunnel syndromes with good relief of symptoms. $\mathrm{He}$ also complained of constipation and numbness of the penis with erectile impotence. There were no symptoms of bladder dysfunction or postural hypotension. $\mathrm{He}$ was of mixed Scottish and English ancestry; extensive genealogical investigation going back to the eighteenth century showed nothing to suggest similarly affected relatives. On examination he had weakness of ankle dorsiflexion and toe extension, absent tendon reflexes and flexor plantar responses. He had distal impairment of pain and temperature sensation, more than loss of light touch in his limbs, and on the anterior abdominal wall, and mild impairment of vibration and position sense in his toes. Serum immunoelectrophoresis was normal. Sensory action potentials were reduced in amplitude in the median $(3 \mu \mathrm{V})$, ulnar $(4 \mu \mathrm{V})$, and sural $(1 \mu \mathrm{V})$ nerves, with mild reduction in conduction velocities, and motor nerve conduction velocities were normal or slightly reduced with small compound muscle action potentials; there was evidence of denervation in distal muscles on electromyography.

A sural nerve fascicular biopsy showed severe depletion of myelinated nerve fibres, particularly those of smaller calibre. There was evidence of both active fibre degeneration and regeneration. Small endoneurial deposits of amyloid were present. The specimen available for immunohistochemistry unfortunately contained no amyloid.

In late 1989 he was found to have cardiac enlargement and a small pleural effusion. Endocardial biopsy showed amyloid deposits; he was treated with diuretics and enalapril. He subsequently developed recurrent symptoms of a right carpal tunnel syndrome and ulnar nerve compression at the elbow; both nerves were decompressed and amyloid was found in the transverse carpal ligament.

Case 3

A 64 year old man from northern France had 
developed bilateral symptoms of the carpal tunnel syndrome when he was aged 54 years, with good recovery after bilateral median nerve decompression. At the age of 63 he developed pain in the small joints of his hands and feet, together with tingling and numbness in his hands and feet. At the time of investigation he had no relevant family history. His father came from Picardy and died at the age of 52 years of carcinoma of the oesophagus; his mother, from Aquitaine, died aged 63 years of uterine carcinoma. They had six and nine siblings respectively, none of whom were known to have symptoms of peripheral neuropathy. On examination in 1988 he showed finger clubbing, swelling of small joints, and axillary lymphadenopathy. $\mathrm{He}$ had mild generalised muscle weakness and distal wasting. He had sensory loss for pain and temperature in a glove and stocking distribution, and his tendon reflexes were absent. There were no signs of autonomic dysfunction. He had atrial fibrillation; echocardiography showed a hypertrophic cardiomyopathy with a suggestion of septal amyloid deposits. Bone marrow and rectal biopsy specimens were normal, as were routine haematological and biochemical results, including immunoelectrophoresis. A sural nerve biopsy specimen showed an appreciable reduction in nerve fibre density, with many fibres undergoing axonal degeneration. There were small endoneurial deposits of amyloid. Amyloid deposits were also found on conjunctival biopsy. Immunostaining was negative for $\kappa$ and $\lambda$ chains, $\beta_{2}$ microglobulin, and TTR. His neuropathy progressed subsequently and he developed postural hypotension; he died suddenly at the age of 67 .

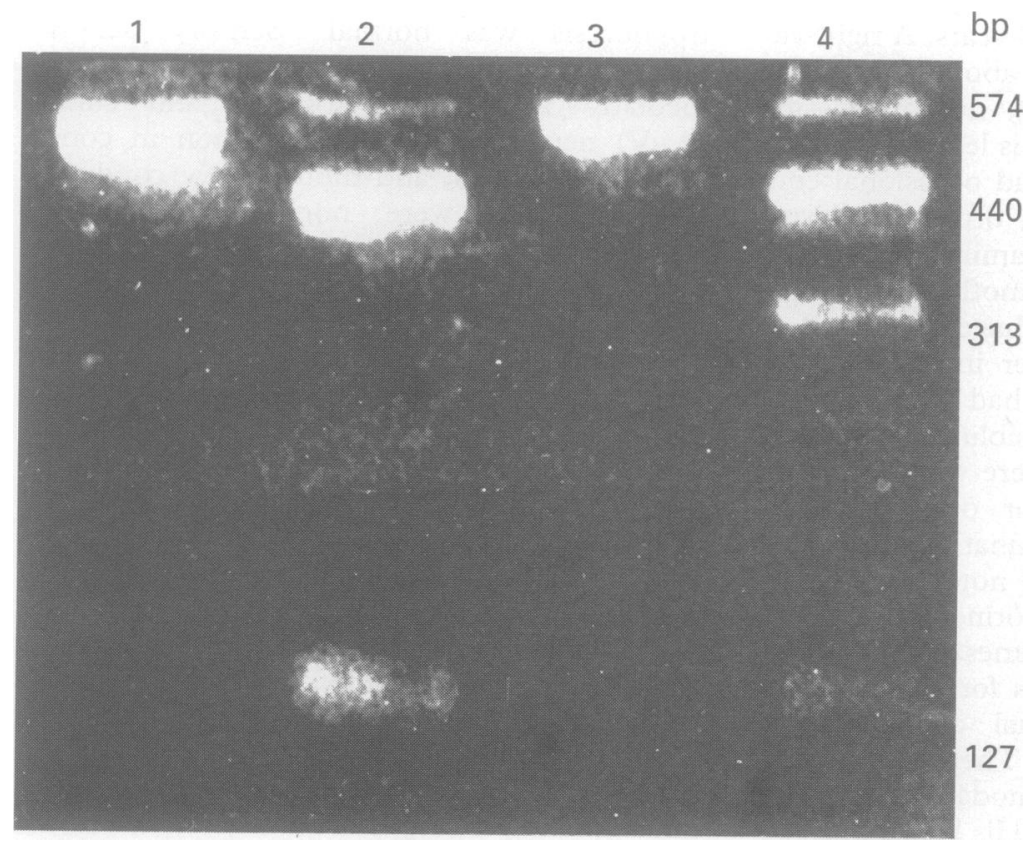

Figure Ethidium bromide stained agarose gel showing products of the polymerase chain reaction after amplification of exon 3 of the TTR gene from a control subject (lanes 1 and 2) and case 3 (lanes 3 and 4). The product is shown undigested (574 bp; lanes 1 and 3) and after digestion with SspI (lanes 2 and 4). Digestion of the control product results in fragments of 440 and $134 \mathrm{bp}$, whereas in the patient the extra restriction site produced by the mutation cleaves the $440 \mathrm{bp}$ fragment from the mutant TTR allele into two of 313 and $127 \mathrm{bp}$, the latter forming a doublet with the normal $134 \mathrm{bp}$ fragment.

\section{Case 4}

In 1991 the 62 year old sister of the patient in case 3 presented with sensory symptoms in her hands and feet and orthostatic hypotension. On examination she had reduced appreciation of pain and temperature sensation distally, with less striking loss of touch, weakness of toe extension, and areflexia. Cardiovascular responses to tilt and the Valsalva manoeuvre were impaired. Nerve biopsy showed amyloid deposits. Echocardiography showed evidence of amyloidosis (concentric hypertrophy and increased echogeneicity of the septum and valves).

\section{Case 5}

A French woman of 67 was the only child of a man from Picardy who died aged 40 years from tuberculosis; her mother, from Eure et Loir, died aged 95 years. She presented with prickling feelings and loss of sensation in her feet. On examination she had loss of pain and temperature sensation in a stocking distribution and absent ankle jerks. Nerve conduction studies showed evidence of an axonal neuropathy, and the features of a subacute axonal neuropathy were seen on sural nerve biopsy. Her condition gradually deteriorated, and when examined at the age of 73 she could walk only with two sticks. She had generalised muscle weakness, most noticeable distally and in her legs, with areflexia. Sensory loss had extended up her limbs and affected the anterior part of the trunk. She was hoarse and had dysuria and constipation. Her pupils were unreactive to light. Amyloidosis was suspected clinically; re-examination of the nerve biopsy sections showed two small deposits in the endoneurium that stained positive with Congo red. Increased echogenicity of the myocardium and thickening of the interventricular septum were seen on echocardiography.

\section{Results}

Case 1 had the TTR met30 mutation, and cases $2-5$ the TTR tyr77 mutation, as shown by the presence of additional restriction sites for $N s i I$ and $S_{s p} I$, respectively (figure).

\section{Discussion}

To our knowledge, cases 1 and 2 are the first patients to be described from the United Kingdom with familial amyloid polyneuropathy defined at a molecular genetic level. The clinical features in case 1 were similar to those reported in Swedish patients with the met30 mutation, with late onset and vitreous involvement. ${ }^{1}$ Patients from Portugal with the same mutation tend to present earlier with sensory and autonomic neuropathy, as described in the introduction of this paper; the reason for these differences in phenotype is unknown.

Wallace et al first described the TTR tyr77 mutation in an Illinois kindred of German extraction. ${ }^{17}$ The proband presented in the sixth decade of life "with symptoms of lower 
limb neuropathy, chronic diarrhoea, and periorbital purpura." His father had similar symptoms and died of renal failure aged 57 years. It is striking that cases 2 and 3 presented with symptoms of the carpal tunnel syndrome, several years before developing a more generalised neuropathy, and these were relieved by surgery. This is also a common presentation in the Indiana/Swiss and Maryland/German types of familial amyloid polyneuropathy. ${ }^{1}$ Late onset neuropathy and cardiac amyloidosis occurred in all four of our patients with the tyr 77 mutation, and also in both members of the French kindred reported with the same TTR variant. ${ }^{23}$ This family came from Picardy, as did the parents of the patients in cases 3-5, and they are probably related. There is no known German or French ancestry in case 2.

As patients 1, 2, 3, and 5 gave no history of affected relatives, familial amyloid polyneuropathy was not considered initially as a clinical diagnosis. These disorders are probably underdiagnosed as the possibility of a genetic disorder is often not entertained in this clinical context. Several TTR mutations clearly show reduced and variable penetrance. Studies in patients from Cyprus and France showed that seven out of 10 with the TTR met30 mutation were sporadic cases. ${ }^{9}$ The potential for late onset in these disorders and the likely probability that the neuropathy and the possibility of amyloidosis are overlooked in some affected patients explains the seemingly sporadic nature of some cases. Furthermore, some gene carriers never develop the disease, even in advanced age. ${ }^{192526}$

These data have important implications for genetic counselling. TTR gene analysis provides a simple non-invasive means of screening patients with amyloid neuropathies, including apparently sporadic cases, and their relatives for the various types of familial amyloid polyneuropathy. Our observations indicate that this is a potentially useful investigation in patients originating outside the areas of Europe where the condition is endemic; it should be applied diagnostically in patients who have peripheral nerve amyloidosis or are suspected of having so on the grounds of having a predominantly small fibre sensory syndrome in the limbs with autonomic features. Amyloid deposits in sural nerve biopsy specimens may be small and overlooked, as in case 5, and are genuinely undetectable in some cases of familial amyloid polyneuropathy because there are sampling problems related to the patchy nature of amyloid deposition. ${ }^{26}$ Also, as indicated in case 3, absence of TTR immunoreactivity in biopsy material does not exclude the possibility of a TTR related neuropathy.

We thank Drs CJF Davis and $M$ Malherbe for referring in cases 2 and 3. Financial support from the Brain Research Trust and the Royal College of Physicians of Ireland is gratefully acknowledged, as is the help of Dr RHM King and Miss f Workman.
1 Benson $\mathrm{MD}$. Inherited amyloidosis. $f$ Med Genet 1991;28:408-26.

2 Andrade C. A peculiar form of peripheral neuropathy. Brain 1952;75:408-26.

3 Saraiva MJM, Costa PP, Goodman DS. Transthyretin (prealbumin) in familial amyloidotic polyneuropathy: genetic and functional aspects. Adv Neurol 988;48:189-200.

4 Saraiva MJM. Recent advances in the molecular pathology of familial amyloid polyneuropathy. Neuromuscular Disorders 1991;1:3-6.

5 Coutinho P, Silva AM, Lima JL, Barbosa AR. Forty years of experience with type 1 amyloid neuropathy: review of 483 cases. In: Glenner GG, Costa P, Freitas AF, eds. Amyloid and amyloidosis. Amsterdam:Excerpta Medica, 1980:88-98.

6 Costa PP, Figuera A, Bravo F. Amyloid fibril protein related to prealbumin in familial amyloidotic polyneuropathy. Proc Natl Acad Sci USA 1978;75:499-503.

7 Saraiva MJM, Birken S, Costa PP, Goodman DS Amyloid fibril protein in familial amyloidotic polyneuropathy, Portuguese type. Definition of molecular abnormality in transthyretin (prealbumin). $\mathcal{F}$ Clin Inves 1984;74:104-19.

8 Ide M, Mita S, Ikegawa S, Maeda S, Shimada K, Araki S. Identification of carriers of mutant prealbumin gene associated with familial amyloid polyneuropathy type 1 by Southern blotting procedures:study of six pedigrees in the Arao region of Japan. Hum Genet 1986;73:281-5.

9 Holt IJ, Harding AE, Middleton L, Chrysostomou G Said G, King RHM, et al. Molecular genetics of amyloid neuropathy in Europe. Lancet 1989;i:524-6.

10 Nakazato $M$, Kangawa $K$, Minamino N, Tawara $S$ Matsuo H, Araki $S$. Revised analysis of amino acid replacement in a prealbumin variant (SKO-III) associated with familial amyloidotic polyneuropathy of Jewish origin. Biochem Biophys Res Commun 1984;123:921-8.

11 Ili S, Minnerath S, Ili K, Dyck PJ, Somner SS. Two tiered DNA-based diagnosis of transthyretin amyloidosis reveals two novel point mutations. Neurology 1991;41:893-8

12 Jones LA, Skare JC, Harding JA, Cohen AS, Milunsky A Skinner M. Proline at position 36: a new transthyretin mutation associated with familial amyloidotic polyneuropathy. Am F Hum Genet 1991;48:979-82.

13 Ueno S, Uemichi T, Takahashi N, Soga F, Yorifuji S Tarui S. Two novel variants of transthyretin identified in Japanese cases with familial amyloidotic polyneuropathy. Biochem Biophys Res Commun 1990;169:1117-21.

14 Almeida MR, Gawinowicz MA, Costa PP, Salvi F, Ferlini A, Plasmati $R$, et al. A new transthyretin variant associa, Plasmati $\mathrm{R}$, et al. A new transthyretin variant associated with familial amyloidotic polyneuropathy in an Italian kindred. In: Natvig JB, Forre O, Husby G, Doordrecht:Kluver, 1990:599-602.

15 Nichols WC, Liepnicks J, McKusick VA, Benson MD Direct sequencing of the gene for Maryland/German familial amyloidotic polyneuropathy type II and genotyping by allele-specific enzymatic amplification. Genomics 1989;5:535-40.

16 Wallace MR, Dwulet FE, Conneally PM, Benson MD Biochemical and molecular genetic characterization of a new variant prealbumin associated with hereditary amyloidosis. $\mathcal{f}$ Clin Invest 1986;78:6-12.

17 Wallace MR, Dwulet FE, Williams EC, Conneally PM, Benson MD. Identification of a new hereditary amyloidosis prealbumin variant, Tyr-77, and detection of the gene by DNA analysis. $\mathcal{I}$ Clin Invest 1988;198:189-93.

18 Dwulet FE, Benson MD. Characterisation of a tranthyretin (prealbumin) variant associated with familial amyloidotic polyneuropathy type II (Indiana/Swiss). $\mathcal{F}$ Clin Invest 1986;78:880-6.

19 Skare JC, Saraiva MJ, Alves IL, Skare IB, Milunsky A Cohen AS, et al. A new mutation causing familial amyloidotic polyneuropathy. Biochem Biophys Res Commun 1989;164:1240-6.

20 Ueno S, Uemichi T, Yorifuji S, Tarui S. A novel variant of transthyretin (Tyr 114 to Cys) deduced from the nucleotide sequence of gene fragments from familial amyloidotic polyneuropathy in Japanese sibling cases. Biochem Biophys Res Commun 1990;169:143-7.

21 Nicols WC, Gregg RE, Brewer HB, Benson MD. Characterisation of a genetic mutation (apolipoprotein Al-Iowa) associated with familial amyloidotic polyneuAl-lowa) associated with familial amylo

22 Haltia M, Levy E, Meretoja J, Fernandez-Madrid I Koivunen O, Frangione B. Gelsolin gene mutation-at codon 187-in familial amyloidosis, Finnish: DNA-diagnostic assay. Am F Med Genet 1991;42:357-9.

23 Satier F, Nichols WC, Benson MD. Diagnosis of familia amyloidotic polyneuropathy in France. Clin Genet 1990;38:469-73.

24 Abbot C, Povey S. Development of human chromosome specific PCR primers for characterisation of somatic cell hybrids. Genomics 1991;9:73-7.

25 Sequeiros J, Saraiva MIM. Onset in the seventh decade and lack of symptoms in heterozygotes for the TTR ${ }^{\text {met30 }}$ mutation in hereditary amyloid neuropathy-type 1 (Portuguese, Andrade). Am 7 Med Genet 1987; 27:345-7.

26 Staunton H, Davis MB, Guiloff RJ, Nakazato M, Harding AE. Donegal amyloidosis is associated with the transthyretin $\mathrm{Ala}^{60}$ (Appalachian) variant. Brain transthyretin Ala 